\title{
West Seti Hydroelectric Project: Assessment of its Contribution to Nepal's Economic Development
}

\author{
Ratna Sansar Shrestha
}

\begin{abstract}
The proposed West Seti Hydroelectric Project, $750 \mathrm{MW}$, is one of the best projects of its genre, because it will not only generate peak-in energy and good quality power but because it will do so at low cost and, furthermore, its implementation will result in flood control and dry season augmented flow for lower riparian areas. Moreover, export of hydropower to India from this project will result in a carbon offset benefit which is tradable on the carbon market and has potential as a good source of revenue. This paper evaluates such benefits and also ascertains to whom such benefits accrue, besides identifying costs (so far unaccounted for). This proj ect's contribution to Nepal's economic development may even be higher by a magnitude if it is to be structured as suggested in this paper.
\end{abstract}

Key words: West Seti, carbon offset, downstream benefit, economic development, export, hydropower, peak-in power, Nepal

\section{Introduction}

ccording to the Environmental Assessment Report Aof West Seti Hydroelectric Project, prepared by West Seti Hydro Limited (WSH 2007), the proposed West Seti Electric Project, 750 MW "will generate and export large quantities of electrical energy to India under a power purchase agreement with PTC (India) Limited, which will in turn sell the power within the northern region of India. Under the terms of the 1997 project agreement between WSH and the Government of Nepal, the Government receives revenue from the sale of power through energy and capacity royalties. In addition, the project agreement incorporates an agreement whereby the Government could receive $10 \%$ of the output of the power station as free power or $10 \%$ of the revenue received under the terms of the power purchase agreement in lieu of free power. The Government chose the latter option. ${ }^{1}$ The Project will generate electrical energy throughout the year, storing excess wet season river flows and utilizing this water to generate energy during peak demand periods in the dry season."

The Project is a build-own-operate-transfer (BOOT) scheme, through which WSH will be granted a 30-year generating license that will provide about 24.5 years of generation before full ownership of the Project is handed over to the Government. To further quote from the same report: "The power purchase agreement has a 25-year term from the date the Project starts commercial operation. The tariff will be on a take-or-pay basis and comprise (i) off-peak energy rate, (ii) peak energy rate, and (iii) excess energy rate. The average tariff will be $\$ 0.0495 /$ kilowatthour at the point of delivery on the Nepal-India border."

TheProjectislocated on theSeti Riverin theFarWestern Development Region of Nepal. The report further states that: "The dam site is located 82 kilometers $(\mathrm{km})$ upstream of the confluence of the Seti and Karnali rivers, forming part of the Ganges basin. The project sites are located in the Middle Mountains, at elevations ranging from 550 to 920 meters $(\mathrm{m})$ and spanning six districts. All project sites, excluding the reservoir area and transmission line corridor, are located in Doti and/or Dadeldhura districts. The reservoir is also located in Baitadi and Bajhang districts, and the transmission line corridor crosses Doti, Dadeldhura, Kailali, and Kanchanpur districts. The project area is accessed by road from the East-West Highway via the Mahakali Rajmarg (H14) and Seti Rajmarg (H15) National Highways, a distance of $139 \mathrm{~km}$."

"The Project consists of four Francis-type vertical-shaft turbines connected to four alternators, each with an output of 187.5 MW at the rated net head. This storage scheme is designed primarily to generate peaking power. The plant is expected to be operated to achieve a target minimum generation of 6 hours per day. The average annual electricity production will total about 3,636 gigawatt-hours (GWh). The main project features are $195 \mathrm{~m}$ high concrete faced rock-fill dam, 2,060 hectare (ha) reservoir area, 6.7 $\mathrm{km}$ headrace tunnel, underground power station, $620 \mathrm{~m}$ tailrace tunnel, re-regulation weir, switchyard, $20.3 \mathrm{~km}$ permanent access roads, and $132.5 \mathrm{~km} 400$ kilovolt (kV) double-circuit transmission line in Nepal."

"The Project will generate power from a head of $259 \mathrm{~m}$, created by running the headrace tunnel across a river bend of the Seti River and thus diverting water around a 19.2 $\mathrm{km}$ river section. The reservoir will fill during the monsoon season (mid J une to late September/ early October), and then water will be drawn down to generate power at peak times each day during the dry season. The reservoir will inundate $25.1 \mathrm{~km}$ of the Seti River and a total of $28.0 \mathrm{~km}$ of five main tributaries (Chama Gad, Dhung Gad, Saili Gad, Nawaghar Gad, and Kalanga Gad). The reservoir will have a total storage capacity of 1,566 million cubic meters $\left(\mathrm{m}^{3}\right)$ (926 million $\mathrm{m}^{3}$ of live storage and 640 million $\mathrm{m}^{3}$ of dead storage) and a drawdown range of $59 \mathrm{~m}$ (from the full supply level to minimum operating level). The peak generation flow will be $330 \mathrm{~m}^{3} / \mathrm{s}$."

In order to assess the contribution of this project to Nepal's economy, an analysis of its benefits, costs and the allocation of thereof is called for; which is the very purpose of this article. In the meantime this paper will also assess 
percolation coefficient of the project. Higher coefficient indicates percolation of funds into Nepal's economy at a higher level which contributes to Nepal's economic development to the commensurate extent.

\section{Part l: Benefits}

This project is one of the best projects of its genre. It generates good quality power - the peak-in energy, at low cost although it is a project with reservoir, the building of which is a costly affair. Furthermore, its implementation results in flood control as well as dry season augmented flow for lower riparian areas. Moreover, export of hydropower to India from this project results in carbon offset benefit which is tradable in the carbon market and has potential as a good source of revenue.

\section{Power benefit}

Even for run-of-river (RoR) projects the industry average cost of installed capacity in Nepal is above $\$ 2,000$ / $\mathrm{kW}$. However, this project's initial investment, as detailed below (SMEC 1997) is only \$1,097 per kW at 1997 price level. The amounts are inclusive of contingency at the rate of $15 \%$ for civil works and $10 \%$ for equipment, project management and resettlement, as provided for in the Detailed Engineering Report of the project.

Built without a reservoir, the installed capacity of this project would have been limited to $100 \mathrm{MW}$. However, as this project has been conceptualized as a reservoir project, the installed capacity has been fixed at $750 \mathrm{MW}$ and it will generate peak-in energy - 3,636 gigawatt-hours (GWh) which normally commands premium price in the electricity market. As its annual average generation (minus 10\% committed for Nepal) is slated to be exported to India at the average tariff of $\$ 0.0495 / \mathrm{kWH}$, this project generates good quality power at low cost. The Nepal Electricity Authority (NEA) is buying electricity from RoR projects built by independent power producers (IPPs) in Nepal at around US $8 \$$ per $\mathrm{kWH}$, on a 'take or pay' basis that forces it to pay the same price for electricity during off hours and off season as well, which gets 'spilled'. Moreover, NEA is importing electricity at around US $9 \$$ per kWh from PTC India Limited. The avoided cost of peak-energy ranges from $\$ 0.20 / \mathrm{kW}$ to $\$ 0.375 / \mathrm{kW}$, depending on the source of energy to the type of institution generating such power (cost being higher for NEA).

The lower export tariff can be ascribed to the long term PPA which mitigates market risk to an extent. Conversely, the electricity tariff could have been higher if PPA is for a shorter term. The phenomenon can be depicted in the following diagram:

PTC India Limited recently proposed to sign a PPA with NEA for 25 years to export electricity from India on a 'take or pay' basis at US $9.6 \$ / \mathrm{kWH} .^{2}$ Similarly, it is interesting to note that Tripura in India had proposed to export electricity to Bangladesh at INR 7 per kWh (equivalent to US 16థ). ${ }^{3}$ This goes a long way to disprove that export tariff for West Seti power has been fixed at a lower level as its PPA duration is for 25 years.

\section{Downstream benefits}

It does not require the knowledge of rocket science to understand that building a reservoir to store water during rainy season and use the stored water to generate electricity around the year does indeed result in flood control during the wet (rainy) season and augmented flow during the dry season. In view of the fact that West Seti is a relatively small river compared to Karnali River (known as Ghagra in India), the flood control benefit due to the reservoir will definitely accrue, but may not be highly significant.

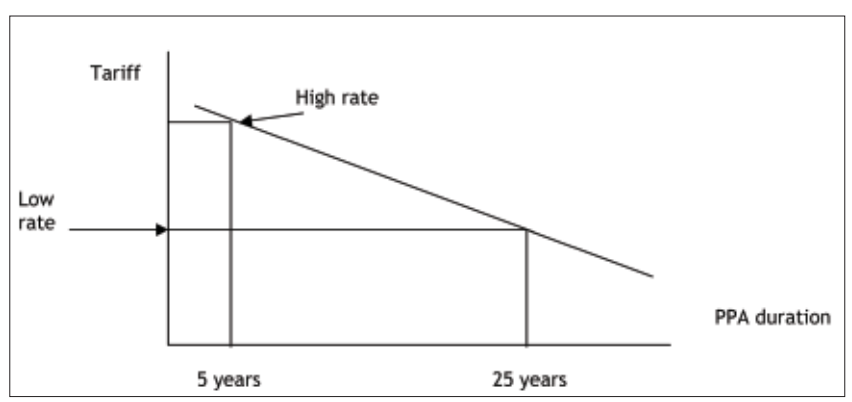

The benefits of flood control manifests in the elimination/reduction of damages due to flood and also in terms of avoidance of expenditure in repairs, maintenance and rehabilitation in the aftermath of flood. Sometimes floods also displace people and the resettlement of them not only costs money but also costs in terms of human trauma and suffering. There is no information available, however, on the quantum of flood control benefit from this project.

Another form of downstream benefit is the availability of augmented flow in the lower riparian areas. According to Dr. Ananda Bahadur Thapa (1995) "After the regulation of the West Seti run-off the present dry season flow at dam site of about 45 cubic meters per second will be increased to about 135 cubic meters per second. Thus the net augmentation of the dry season flow could be about 90 cubic meters per second." Additional flow as such is invaluable for purposes of both irrigation and water supply in the lower riparian areas.

This quantum of augmented flow during the dry season (8 months) is worth $\$ 83$ million (equivalent to Rs 6 billion approximately) annually based on the principle set forth by the treaty between Lesotho and South Africa. South Africa pays a lump sum of $\$ 25$ million (in 1991 prices) each year to Lesotho for supplying $18 \mathrm{~m}^{3} / \mathrm{s}$ of water (both for the purpose of irrigation and water supply) from Lesotho Highlands Water Project (Wallis 1992).

A mechanism could also be developed to share such benefit on the precedent set by the Columbia Treaty. Under Article V: Entitlement to Downstream Power Benefits of this treaty "Canada is entitled to one half the downstream power benefits." The downstream power benefit has been defined by ArticleVII as "the difference in the hydroelectric power capable of being generated in the United States of America with and without the use of Canadian storage." Drawinga parallel with theWest Seti Project, as theinstalled capacity of this project without a reservoir is just $100 \mathrm{MW}$, the power benefit of the construction of the reservoir is 
650 MW and Nepal, under the principle established by this Treaty, is entitled to $325 \mathrm{MW}$.

Similarly, under Article VI of this treaty, Canada gets a lump sum of \$64,400,000 as "Payment for Flood Control" from the USA. Additionally "the United States of America shall pay Canada in United States funds in respect only of each of the first four flood periods for which a call is made 1,875,000 dollars and shall deliver to Canada in respect of each and every call made, electric power equal to the hydroelectric power lost by Canada as a result of operating the storage to meet the flood control need for which the call was made," moreover, under Clause (b) of Section 4 of this article US is required to pay to Canada a "compensation for the economic loss to Canada arising directly from Canada foregoing alternative uses of the storage used to provide the flood control."

Unfortunately, the extant paper work between Nepal and the proponents of the West Seti Project have deprived Nepal of these innate rights. Nepal deserves to be recompensed for the downstream augmented flow based on the lines of agreement between Lesotho and South Africa or on the basis of the precedent set by the Columbia Treaty. Failing to emulate the principles set in one of these treaties, there is no point in implementing this project.

Recall that the data on augmented flow of $90 \mathrm{~m}^{3} / \mathrm{s}$ is based on the concept of building a dam of $187 \mathrm{~m}$ height, with a storage capacity of 1,600 million $\mathrm{m}^{3}$ and installed capacity of $360 \mathrm{MW}$ only. With the increase in the height of the dam to $195 \mathrm{~m}$ and installed capacity to $750 \mathrm{MW}$ there must be commensurate increase in the augmented flow.

\section{Climate change - carbon offset}

Emission of carbon dioxide $\left(\mathrm{CO}_{2}\right)$ from the use of fossil fuel has resulted in global warming on a large scale that, in turn, has induced climate change. In order to mitigate this problem, the Clean Development Mechanism (CDM) has been put in place, which is a mechanism within the Kyoto Protocol that allows industrialized Annex-I countries to implement projects that reduce emissions in non-AnnexI countries (developing countries) and get credits for meeting their commitments to reduce emissions.

Generation of hydropower does result in environmental additionality due to carbon offset by it, in not emitting green house gases (GHG) in the environment. As envisaged by the Kyoto Protocol, trading in such carbon offset, also known as carbon credit, is already taking place. However, as Nepal is bereft of any fossil fuel exploration activity, and its use of such polluting source of energy as a source for electricity generation is negligible; therefore, Nepal's baseline is deemed to be the hydropower which doesn't pollute. Under the Kyoto Protocol, a country like Nepal with hydropower as its baseline, environmental additionality is not deemed to be accrued by generating additional hydropower for domestic use, except in the case of hydropower plant of up to $15 \mathrm{MW}$. Therefore, most of the projects are not considered to be generating environmental additionality. Whereas the West Seti Project is slated to export 'clean' power to a country whose baseline is unclean, the transaction does succeed in offsetting $\mathrm{CO}_{2}$.

In view of this, export of hydropower from Nepal to India is a good candidate for trading in carbon credits and for which the West Seti Project is in a comparatively good position. Of the annual generation of 3,636 GWh, this project is obliged to provide $10 \%$ to Nepal free of cost and it will be exporting 3,272 GWh to India each year. In view of this, export of hydropower from Nepal to India is a good candidate for trading in carbon credits and for which West Seti project is in a comparatively better position to do so. Of the annual generation of 3,636 GWh, this project is obliged to provide $10 \%$ to Nepal free of cost and it will be exporting 3,272 GWh to India each year. Pankaj Patel and Raga Ragavan have conducted a study have not only determined the carbon offset on an annual basis by the project but have also worked out the GHG that the rotting vegetation in the reservoir will be producing. Their computation is as tabulated below:

Estimated greenhouse gases produced and reduced annually by the West Seti Project

\begin{tabular}{|c|c|c|c|c|c|c|}
\hline Gas & GWP & $\begin{array}{c}\text { Reduced } \\
\text { (tons) }\end{array}$ & $\begin{array}{c}\text { Produced } \\
\text { (tons) }\end{array}$ & $\begin{array}{c}\text { Equivalent } \\
\text { GWP reduced }\end{array}$ & $\begin{array}{c}\text { Equivalent GWP } \\
\text { produced }\end{array}$ & $\begin{array}{c}\text { GWP } \\
\text { Balance }\end{array}$ \\
\hline $\mathrm{CO}_{2}$ & 1 & $3,449,032$ & & $3,449,032$ & & \\
\hline $\mathrm{CH}_{4}$ & 21 & 21.84 & 104.5 & 458.64 & 2,194 & \\
\hline $\mathrm{N}_{2} \mathrm{O}$ & 310 & 27.97 & & 8,670 & & \\
\hline Total & & $3,449,081$ & 104.5 & $3,458,160$ & 2,194 & $3,455,966$ \\
\hline
\end{tabular}

In sum the export of electricity from this project will offset 3,458,160 tons of $\mathrm{CO} 2$ equivalent in a year while the reservoir will produce 2,194 tons of $\mathrm{CO} 2$ equivalent over the year resulting in a net offset of 3.45 million tons of $\mathrm{CO} 2$ equivalent. Such carbon offset has a market under Kyoto Protocol. Although the price of carbon offset ranges between $\$ 5$ to $\$ 15$ per ton of CO2 equivalent, for the sake of simplicity, using a median price of $\$ 10$ per ton of CO2 equivalent yields a revenue stream of \$ 34.5 million (equivalent to Rs 2.59 billion) per annum.

In view of the numerous benefits, as described above, that construction of this project will result in, this is definitely one of the best projects of the genre. However, benefits don't come alone and there are always numerous and matching costs.

\section{Part II: Costs}

Besides the initial investment which is the financial cost to the project developer, there are costs involved in building this project in terms of environmental degradation, submergence of forest, cultivable land, displacement of local populace, etc., that Nepal will have to internalize.

\section{Inundation/ submergence}

The project's reservoir inundates/submerges 25.1 $\mathrm{km}$ of the Seti River and a total of $28.0 \mathrm{~km}$ of five main tributaries (Chama Gad, Dhung Gad, Saili Gad, Nawaghar Gad, and Kalanga Gad) (WSHL 2007). According to the same report "The permanent project features will require the acquisition" of "659 ha cultivated land, 806 ha forest, 
169 ha shrubs, 246 ha grassland, 9 ha abandoned land, 5 ha settlement, 409 ha river bank land and 23 ha rock/ cliffs totaling 2,326 ha of land". ${ }^{4}$ Similarly, 678 ha will be "utilized for the transmission line ROW" (right-of-way). In total the project will use 3,004 ha of land permanently.

The acquisition of land as such is covered by the EIA report. The project proponent has plans to resettle the displaced peopleby providingland in lieu of cultivated land. However, the land occupied/cultivated by the displaced populace is just 659 ha, comprising $22 \%$ of total land to be acquired and used by the project. In order to resettle the displaced people, the project will be providing land in lieu for the cultivated land in Nepal. In this manner the project will be using Nepal's additional land for the purposes of resettlement. However, the project has no plans to provide land in lieu of remaining 2345 ha of land (3,004 ha minus 659 ha) that the project is to use. An important question that arises is why Nepal should sacrifice 2,345 ha of its land to provide good quality low cost power to India, which will also enjoy the benefit of flood control in rainy season and augmented flow in the dry season.

\section{Additional inundation/ submergence}

Currently 1,630 ha land gets submerged completely and 645 ha partially every rainy season in Banke district (in Holiya, Bethani, Gangapur, Matehiya and Phattepur VDCs) due to Laxmanpur barrage built by India (Dhungel and Pun, et al 2009). According to Dr Anand Bahadur Thapa (2009) "the controversial Laxmanpur barrage located very close to Indo-Nepal border is a direct extension of the West Seti storage dam project. People of Banke district are already suffering from the partial submergence after completion of the Laxmanpur Project. The flooding situation would greatly worsen once the West Seti Project starts to operate." Upon completion of this project the area will be submerged in the dry season too (as there will be additional water in the barrage in the dry season) resulting in submergence throughout the year due to the augmented flow. This aspect is not covered by the EIA report and, therefore, no resettlement and rehabilitation plan has been put in place. This impels one to wonder if the project proponents have disclosed full facts about the project to the Asian Development Bank, principal financier of the project.

Mr Shiv Kumar Sharma, Regional Director, Mid Western Regional Irrigation Directorate, under Ministry of Irrigation (located in Birendranagar) disagrees with Dr Thapa's contention, however, and opines that the Laxmanpur barrage will not cause additional inundation in Banke District during dry season.

\section{Displacement of local people}

Theinundation/ submergencedescribed abovedisplaces 18,269 people according to the EIA report (WSHL 2007). The proponents of the project claim to have put in place a plan to resettle and rehabilitate these people. However, the project doesn't have any plan to resettle 15,174 people that will be displaced completely after this project comes into operation due to Laxmanpur barrage in India (Dhungel and Pun, et al 2009).

\section{Upstream area to cede water rights}

Clause 7.2(d) of the Project Agreement, and Rule 20 of Electricity Regulations of 2050 BS, put restrictions on the consumptive use of water in the upstream area in order to ensureadequatewater for the project to generateelectricity. This restriction adversely impacts the following VDCs, which will not be allowed to use water in the upstream area for consumptive uses like irrigation etc.: Rayal, Dangaji, Parakatne, Bhairabnath, Chaughari, Kotbhairab, Malumela, Matela, Subeda, Luyata, Hemantabada, Chainpur, Sunkuda, Banjh, Khiratadi, Dahabagar, Pipalkot and Kapalseri in Bajhang District, Belapur in Dadeldhura District, Shivalinga, Dhungad, Sigas and Thalakada in Baitadi District and Lamikhal, Mahadevsthan, Dahal Kalikasthan, Girichauka and Chhapali in Doti District. The project people are trying to undermine the importance of the issue by saying that there will not be any restriction on drawing of water by the people in these villages for the purposes of drinking. The important issue here is water for irrigation purposes. Due to the restriction imposed by Clause 7.2(d) of the Project Agreement, and Rule 20 of Electricity Regulations of 2050, no new irrigation work will be allowed to be undertaken in these villages. Their attempt to obfuscate the matter will not help the project. Rather, this is the best way to lose their own credibility in the eyes of the people adversely impacted by the project in particular and others in general.

\section{Dewatered area}

The project will be diverting water around $19.2 \mathrm{~km}$ river section and this patch of the river will become dewatered. Water will become unavailable for use by locals in such de-watered area. Bayarpada, Banlek, Jijaudamandu, Latamandu and Pachanali VDCs in Doti District and Belapur in Dadeldhura District will be adversely impacted. The environmental flow of $10 \%$ that the project is required to release in the dewatered area will not be adequate for the residents of the villages on the banks of the dewatered river to undertake irrigation work.

\section{Part III: Allocation of Benefit and Cost}

After having established various benefits and costs of the project, it is time to assess how such benefits and costs are allocated (as to who enjoys the benefits and who bears the cost), which is depicted in the table below:

\begin{tabular}{|l|c|c|}
\hline \multicolumn{1}{|c|}{ Benefit } & Nepal & India \\
\hline Good Quality Power & & $\checkmark$ \\
\hline Low-cost Power & & $\checkmark$ \\
\hline Flood Control & & $\checkmark$ \\
\hline Dry Season Augmented Flow & & $\checkmark$ \\
\hline Carbon Trading Benefit & & $\checkmark$ \\
\hline \multicolumn{1}{|c|}{ Cost } & Nepal & India \\
\hline Inundation/ Submergence & $\checkmark$ & \\
\hline Displacement of People & $\checkmark$ & \\
\hline
\end{tabular}




\begin{tabular}{|l|c|c|}
\hline $\begin{array}{l}\text { Additional Inundation/ } \\
\text { Submergence due to Laxmanpur }\end{array}$ & $\checkmark$ & \\
\hline $\begin{array}{l}\text { Additional Displacement of } \\
\text { People in Banke }\end{array}$ & $\checkmark$ & \\
\hline $\begin{array}{l}\text { Restriction on Consumptive Use } \\
\text { of Water in Upstream Area }\end{array}$ & $\checkmark$ & \\
\hline $\begin{array}{l}\text { Water unavailable in } \\
\text { de-watered area }\end{array}$ & $\checkmark$ & \\
\hline
\end{tabular}

From the above table it is clear that all of the costs have to be borne by Nepal while benefits go to India making one wonder why Nepal is allowing the implementation of such a project.

The question that occurs to patriotic/nationalist Nepalese people is why should Nepal sacrifice 4,634 ha of land permanently and 645 ha partially (including submergence in Banke District that has not been accounted for by the project proponents) in order to provide (a) good quality power at low cost, (b) flood control in the rainy season and augmented dry season flow free of cost to India and also (c) carbon offset benefit to India. As a country there is sense in inundating its land mass in one area in order to benefit other area in terms of flood control and augmented flow which will help increase cropping intensity, including off season planting of high value agricultural produces. But that is not the case here. Inundation happens in Nepal and benefits accrue to India.

There is no doubt whatsoever that storing water during the rainy season in the reservoir built for electricity generation will augment the flow in the Seti River in the dry season and, consequently, in the Karnali in Nepal and the Ghagra in India substantially. As $75 \%$ of the dry season flow of the Ganga River is contributed by rivers in Nepal, the Karnali being one of the major ones, the incremental flow will be significant. The only issue that needs to be settled is the quantum of such augmented flow, objectively. Dr Anand B. Thapa, an eminent scholar, has opined that it will amount to $90 \mathrm{~m}^{3} / \mathrm{s}$, while others feel that this is a slightly overestimated quantum. The issue that needs to be debated is not how much will be augmented - which can be scientifically assessed - but why should Nepal have its land, forest, infrastructure, etc., submerged and have its populace displaced in order to provide additional fresh water to India free of cost.

There are people in Nepal who are happy to surrender everything to India, even Nepal's sovereignty, while paying lip serviceto thespirit of workingto thebestinterest of Nepal and its people. But the majority, thankfully, will never agree to the sell out Nepal's interest in any form. Unfortunately, the majority is neither well informed nor in a position to stopthehydrocracy (politicos, bureaucracyandintellectuals involved in water resource sector development) from signing away Nepal's interest in treaty after treaty, resulting in treaties for Nepal's major rivers like the Koshi, Gandaki and Mahakali. ${ }^{5}$ That was a phase where such bi-national treaties were signed and a lot of controversy raised. These people, with the inclusion of Article 126 in the Constitution of 1990 (Article 156 in Interim Constitution), requiring ratification of such treaties by simple majority in the case of treaties of ordinary nature and by two-thirds in the case of treaties that affect the nation extensively, seriously or in the long term, have changed track. They are now putting forth fronting companies which secure Indian interest in Nepal's water by getting licenses for hydropower. Thus, in the name of hydropower development, Nepal's land, forest, infrastructure, etc., is submerged and its populace displaced to provide flood control benefit and augmented flow in the dry season free of cost to India.

India's former Water Resources Minister, Mr Saif Uddin Soz, was frank and honest in admitting to Navin Singh Khadka of the BBC Nepali Service, on 12 September 2008, that "Our main interest is flood control and irrigation. Those are our first and second priority. If we get hydroelectricity as by product, that will be a bonus for us." ${ }^{\prime 6}$ This is the first time that an Indian official (of the highest level) has been candid in admitting as much. Surprisingly, however, this has yet to be understood by Nepal's hydrocracy. Or, it may be a case of them pretending not to understand it in order to ensure that Indian interest is served by implementing projects in the name of hydropower that afford flood control benefit and augmented flow at no cost to India. What galls the ordinary Nepalese citizenry is the fact that these people parrot the statement that they are working to serve the best interest of Nepal and its people while betraying the nation and the population no end.

This breed of 'patriotic' people even sarcastically dismiss the issue by saying that the water from the tailrace of the West Seti Project will not just jump into Indian territory, and go on to add that between the tailrace and Indian territory the augmented flow traverses over $100 \mathrm{~km}$ of Nepalese territory. What they don't admit is the fact that if the West Seti Project isn't to be built as a multipurpose project, with an objective to irrigate Nepalese land by using the augmented flow, but that the augmented flow will fall in India's lap as a low hanging ripe fruit, and after using such water during a couple of seasons they will have a strong case to invoke the principle of "existing prior consumptive use." It is well known by now that using this very principle the water from Mahakali River - deemed to be a border river and each country being entitled to half water - India got away with $96.5 \%$ water, leaving just 3.5\% for Nepal. Interestingly, this breed of people even come to the defense of the treaty - and by extension of India - by arguing that it doesn't make sense for Nepalese people to clamor for 50\% share of the water when Nepal isn't even able to use 3.5\% (such is their patriotism!).

Some proclaim that Nepal does not have exclusive right over water flowing in rivers in Nepal as they deem these as international water course. Even if one accepts the logic of international water course, the augmented flow will not be the 'same' water. What the proponents of this concept need to understand is that the augmented flow generated by storing it in a reservoir inundating Nepal's land is the water with temporal value added at Nepal's cost. Therefore, Nepal is entitled to the 'value' that has been created/added by way of storage of such water in Nepalese territory. The 
problem lies in their mindset that the water flows down to India anyway. The water that flows down during the normal course is the water which is devoid of any value addition. Such water even causes flood during rainy season. But by building a reservoir additional value will be created/added on the free flowing water. Therefore, Nepal is entitled to a 'fee' for the value added. People advocating to provide such value added water to India free of cost can in no way be deemed to be working for the interest of Nepal and its people. This thinking on their part is the other half of the oxymoronic statement that the water normally flowing in the river is a waste of 'valuable' water. They don't tire of attributing value (hence the relevance of wastage) to the naturally flowing water, which is bereft of any value addition (neither spatial, nor temporal), but are adamant to bestow value added water free of cost to India.

Carbon offset does indeed occur by the export of hydropower from Nepal to India. It is also true that, due to submerged vegetation in the reservoir, methane is also generated by the reservoir. If the carbon offset by the former is more than carbon equivalent emitted by thelatter, then there is considerable value in such carbon offset. A pragmatic approach on the part of Nepalese hydrocracy would have been to ensure that Nepal isn't shortchanged of the proceeds of carbon trading emanating from the export of hydropower from the West Seti Project. But this section of hydrocracy that profess their love for Nepal, wish that no question like this is raised such that Indian establishment becomes annoyed at the ineffectiveness of Nepalese hydrocracy in protecting the Indian interest. The West Seti Project management opines that carbon offset hasn't been traded for projects larger than $200 \mathrm{MW}$. This raises two issues: (1) that there is no harm in trying for a larger project, and (2) that it is incumbent on the Government of Nepal to ensure that if any carbon offset from this project is traded in the future, Nepal's rights are protected.

Therefore, under the arrangement for the West Seti Project, Nepal gets shortchanged in many ways. She has to internalize various costs like inundation/ submergence by the reservoir and in Banke district, displacement of people, restriction on consumptive (irrigation) use of water in upstream area, unavailability of water in de-watered area to irrigate. While providing good quality power to India at low cost on top of providing benefit from flood control, augmented flow and carbon trading.

\section{Allurement}

In this backdrop one wonders why Nepal is determined to go ahead with this project! The transfer of the power plant to Nepal after 30 years, free of cost has been used (even by the Supreme Court) to justify Nepal internalizing all the costs mentioned above to export peak-in energy at rock bottom price. However, India will keep flood control and augmented flow benefits permanently (even after handover of the plant in 30 years), as the "existing prior consumptive use" principle will kick in while Nepal will lose 3,004 ha under the reservoir and 1,630 ha permanently,
645 ha partially in Banke due to Laxmanpur barrage coupled with the augmented flow to India. In this backdrop it is hard to accept that even Supreme Court verdict has served national interest.

What has been said by the project proponents (echoed with glee by Nepal's hydrocracy) is that Nepal will receive a project worth $\$ 1.2$ billion, free of cost in 30 years. This has got a cross section of Nepalese hydrocracy enthralled, which has succeeded in spreading the contagion to the uninformed general public. It needs to be remembered that the present value of $\$ 1.2$ billion, discounted at the rate of $10 \%$, to be received 30 -year hence is just $\$ 68.77$ million - not a huge amount worth to be excited about. Similarly, looking at it from another perspective, depreciated value of the asset worth $\$ 1.2$ billion today in 30 years is just, again, $\$ 48$ million (after depreciating the property for 24 years, with 25 years as the economic life of the project). As the old saying goes, it will be tantamount to people going about bragging about having put on some weight while it was merely a case of swelling of the body. Because, thirdly, by then, although the civil works part may be in a fairly good condition but same will not be true in the case of hydro and electro-mechanical equipment which will have to be replaced in about $25-30$ years.

On the contrary Nepal stands to be shortchanged of $\$ 2.075$ billion (at current price level) for the augmented flow of water over 25 years, ${ }^{7}$ even if Nepal is to get back the augmented flow too after the handover of the project. Similarly, Nepal also is not going to receive $\$ 34.5$ million for the carbon offset during 25 years operation of the plant that she is entitled to. Moreover, it also needs to be remembered that this calculation does not take into account the power benefit that is due to Nepal.

In this scenario, Nepal does not get what is rightfully due to it. But even after hand over of the project India will continue to keep benefit from flood control as well as from the augmented flow. She will end up having right to these permanently as she will use the principle of "existing prior consumptiveuse." In Nepal's case, theland inundated by the reservoir and Laxmanpur barrage will continue to remain unavailable to her permanently, till decommissioning of the plant.

\section{Decommissioning}

Besides, there is the issue of decommissioning, ${ }^{8}$ about which both the hydrocracy and the project people don't like to talk. Although the main source of Kulekhani reservoir, for example, is not based on silt laden river, the dead storage of this reservoir is already $25 \%$. In other words, the capacity of Kulekhani reservoir has diminished to $75 \%$ of original capacity in about 2 decades. Same (the role of silt) can also be seen from the rise of river-bed of Koshi River by four meters, compared to the level of the land in the surrounding area. The Seti River also carries a high silt load and the West Seti Project will transform into a RoR project from the reservoir project in about 30-40 years. At that time, after getting it handed over to Nepal, this project's dam will have to be decommissioned. 
As the private sector has not provided any budget for this purpose, the government of Nepal will be forced to spend money to accomplish it, which means that when Nepal is supposed to be 'enjoying' electricity from this project handed over free of cost, she will be forced to shell out money for decommissioning that will cost more than the initial investment to build this project.

\section{Part IV: Assessment of Percolation Coefficient}

An objective assessment of a project also needs an assessment from economic perspective. The best way to do so is by examining/analyzing various linkages to the economy like backward, forward, investment and fiscal linkages of the specific projects and evaluating the contribution to the national economy in terms of percolation coefficient. Implementation of a hydropower project entails investing a huge amount, which results in backward linkage, provided that the amount invested as such percolates into the economy. Similarly, commissioning a hydropower project results in forward linkage and the percolation coefficient from it depends on the use of the output (electricity) from it within the economy. An economy can also benefit from investment linkage depending upon the flow of return on investment from the hydropower project - i.e., whether it percolates within the economy or without. Finally, a national treasury benefits from fiscal linkage due to implementation of the project to the extent of various rates and taxes paid by the project.

\section{Backward linkage}

Hydropower projects are of a capital intensive nature, entailing high initial investment. Depending on the nature of backward linkages of a specific project, the contribution of each project to the country's economy can be assessed by evaluating how much of the initial investment is retained by the economy, resulting in employment generation, higher level of industrialization, increased contribution to foreign exchange reserve, capacity enhancement and capital formation. The absorption capacity of the economy also dictates the value/volume of the backward linkage. If the full amount of investment for this project is to percolate into Nepal's economy, she would definitely benefit substantially.

Obviously, if closer to a 100 percent of the initial investment percolates into the economy, the contribution of such a project to the economy due to backward linkage will be very high. Conversely, if the economy is able to retain very little of the initial investment then the benefit accruing to the economy from such a project will be proportionately low. From this perspective, a project which makes substantial contribution to the economy due to backward linkage is good for the country and vice versa.

Let's examine the percolation coefficient due to backward linkage of this project. According to Table 1, above, implementing this project entails investing \$1.097 billion. Of the total cost of civil works of $\$ 469$ million, most of it will be incurred for the procurement of cement, steel

\begin{tabular}{|l|c|}
\hline \multicolumn{1}{|c|}{ Description } & $\begin{array}{c}\text { Amount in } \\
\text { million USD }\end{array}$ \\
\hline Civil works & 469 \\
\hline Electro-mechanical & 180 \\
\hline Transmission & 22 \\
\hline Resettlement & 25 \\
\hline Project Management & 67 \\
\hline MIGA & 34 \\
\hline Interest during construction and other financing cost & 255 \\
\hline Legal costs & 18 \\
\hline Development cost & 27 \\
\hline Total initial investment in million USD & 1,097 \\
\hline
\end{tabular}

Table 1. Detail of Initial Investment

bars and other construction materials. Although there are two cement factories (other factories mainly grind imported clinker and fill in the sacks), theproduction capacity of these is not adequate to meet even present domestic demand. There are also a number of factories producing steel bars in Nepal, but these too are unable to meet domestic demand (and, moreover, as they use imported raw materials, the percolation from the use of such steel bars into the Nepalese economy is very little). Therefore, the requirement of this project will have to be met from imports. The project will, however, be able to source for gravel, aggregate, sand, etc., within Nepal at an estimated cost of about \$1 million.

As Nepal is yet to set up industries manufacturing/ fabricating electro-mechanical equipment even for projects below $10 \mathrm{MW}$, the entire budget of $\$ 180$ million is likely to be spent on imports of electro-mechanical equipment for this project. The same will be the case of investment of $\$ 22$ million in the transmission lines. It can be fairly assumed, however, that it will cost about \$1 million in Nepalese workers for the installation/ erection of electro-mechanical equipment and transmission network.

The resettlement entails purchasing land and building houses for the displaced populace and the land is expected to cost $50 \%$ of the budget and construction materials also $50 \%$. Project management, to be the responsibility of SMEC, is expected to be predominantly expatriate affair and about $10 \%$ is expected to be spent on the technocrats from Nepal.

SMEC has been making it public that 5,000 unskilled workers are expected to get employment during the construction period (as have been seen during the construction of most of the hydropower projects, most of the skilled workers will be sourced from foreign countries). Over the construction period, lasting 5.5 years, the workforce at the construction site will be relatively small in the initial years which will peak during the 4 th year and will taper off as the time of commissioning of the plant nears. Therefore, it is estimated that the construction of the project will entail 165,000 worker/ months. Total payment to the workers over the construction period is estimated to amount \$15 million at the rate of Rs 6,000 per worker/ month.

Multilateral Investment Guarantee Agency (MIGA), being a member of the World Bank group, the premium 
of \$34 million will be spent overseas. Similarly, as debt financing for the project will be coming from foreign financial intermediaries, the interest during construction and other financing costs will not percolate into Nepalese economy. It is expected that about $\$ 0.2$ million will bespent on lawyers from Nepal and the balance of \$17.8 million will be paid out to foreign lawyers. SMEC is entitled to a development cost of $\$ 27$ million for preparing the project and it can be fairly assumed that about $10 \%$ of this amount will be spent in Nepal.

In this manner, of the total initial investment of \$1,097 million, about \$39 million will be spent in Nepal - resulting in percolation coefficient of 0.0356 . Therefore, the employment generation, level of industrialization, capacity enhancement and capital formation will belimited by this percentage. In a similar vein, although this project entails foreign direct investment of $\$ 1,097$ million, but the contribution to the foreign exchange reserve of Nepal (another form of backward linkage) will, too, be limited to \$39 million that will be spent in Nepal. The rest will come to Nepal as the foreign direct investment and will desert the country immediately due to outlays in foreign countries.

If the absorption capacity of the Nepalese economy would be better, the percolation coefficient of this project from backward linkage would be higher. Conversely, percolation coefficient of other projects which are not too dependent on foreign sources will be higher. An ideal hydropower project from this perspective will result in 0.5 or more percolation coefficient.

\section{Forward linkage}

Another important way that a hydropower project can benefit an economy is from forward linkage benefits, which entail using the electricity domestically. Use of electricity by an economy results in the multiplier effect on the economy resulting in employment generation, higher level of industrialization, increased contribution to foreign exchange reserve, capacity enhancement and capital formation. The electricity, when it becomes available, can be used in all sectors; e.g., in agro-processing, liketea which is currently processed using furnace oil or firewood. With this one change the economy will benefit from decrease in the import of fossil fuels that drain hard currency, as well as in a decrease in deforestation and a decrease in environmental pollution. Similarly, by using electricity for irrigation, farmers will benefit due to increase in cropping intensity, plantation of cash crop, off season produce, etc.

Currently, industrialization in Nepal is stifled due to non-availability of abundant electric energy. Even existing industries have to rely on fossil fuels which are not cost effective - resulting in higher cost of production that impacts both the industry and its consumers. It also drains foreign exchange reserve and it results in environmental pollution due to emission of greenhouse gasses. The fate of the transport sector is also not different from industry, both of which are heavily dependent on imported fossil fuels requiring convertible foreign exchange. The result is environmental pollution on a massive scale. Similar parallels can be drawn with tourism, health, education and domestic sectors.

If the electricity generated from a project like West Seti is to be used domestically, the forward linkage benefit to Nepalese economy would be tremendous. In order to simplify the matter, as only $10 \%$ of electricity generated from this project will be available to the Nepalese economy, ${ }^{9}$ we can conclude that the percolation coefficient of this project is 0.1 on account of forward linkage. On this issue, too, it is curious that such a project that will not only generate good quality electricity at low cost but also flood control and augmented flow, the free energy given is at the lowest level. The Upper Karnali and Arun III projects have offered $12 \%$ and $21.9 \%$ free energy.

From the above it is clear that the use of electricity generated by a project results in import substitution to an extent, and, therefore, it positively impacts the foreign exchange reserve, too. There are 'economists', however, who believe that exporting electricity from such a project to India helps mitigate the problem of balance of payment deficit of Indian currency - to the extent of total revenue generated by this project by exporting electricity. This, unfortunately, is untrue, which can be substantiated by looking at future cash flow of the project subsequent to its commissioning. For the duration of debt service period of about 15 years, of the total revenue generated by this project a large portion will be used up in the payment of interest on the debt and repayment of a part of the principal. Anything left after meeting the debt service requirement and the operation and maintenance costs will be distributed as dividends, of which only 15\% will reach Nepal. However, as Government of Nepal is borrowing money to invest in the equity of this project. Most of the money from dividend in the hands of the government will be spent in meeting this part of the debt service obligation. Therefore, the only 'foreign exchange' that will enter and stay in Nepal in the first 15 years of project operation are the energy and capacity royalties, which adds up to about $2.89 \%$ of the total export revenue in the case of this project (this is further elaborated under fiscal linkage below).

\section{Investment linkage}

Under investment linkage the economy will benefit due to construction and operation of the project from the perspectiveofreturn oninvestment. Thereturn, in thehands of the recipient, will either be used as increased purchasing power, which will result in employment generation or will be saved and invested again, resulting in capital formation. If a project is fully financed domestically then the financial intermediaries will haveearned interest on theirinvestment and the equity holders will have received dividend both of which would have stayed in Nepalese economy.

In the case of the West Seti Project, as all debt is being sourced from foreign financial intermediaries and all equity investors are foreigners, except for $15 \%$ of GoN almost all of the return on investment will not percolate into the Nepalese economy. If the GoN was to take up $15 \%$ equity in this project from domestic sources, at least $3.75 \%$ of 
the return from the project would accrue to Nepal. But, as GoN is borrowing money to invest in this project whatever dividend GoN will receive from this project will flow right back to the lender in debt service (repayment of part of the principal and interest on the loan outstanding). Therefore, the percolation coefficient on account of investment linkage is 0.01 .

\section{Fiscal linkage}

The fiscal linkage of a project to the economy of the country manifests in its contribution to the treasury in the form of payment of various rates, taxes and duties. During the operational period, this project is required to pay capacity royalty of Rs 100 per $\mathrm{kW}$ and energy royalty of $2 \%$ of the revenue during first 15 years of the project operation which amounts to $2.66 \%$ of theturnover (whereas theUpper Karnali and Arun III projects are required to pay royalty at the rate of Rs $400 / \mathrm{kW}$ and $7.5 \%$ as energy royalty). Under current Nepal law, a hydropower project is required to pay income (corporate) tax at the rate of $20 \%$ of the net income post commissioning. West Seti Project, however, is exempt from paying income (corporate) tax. Therefore, this project will not be paying any taxes to GoN during the first 15 years' operation, except for a very meager export tax of $0.05 \%$ of the revenue, which other projects do not pay. Other projects will be paying income tax at the rate of $20 \%$ of the net income, which works out to over $7 \%$ of the revenue during the first eight years (debt service period) and exceeds $14 \%$ from $9^{\text {th }}$ year onwards.

Under the Project Agreement, however, GoN has exempted even the tax on interest paid out to the lenders and dividend distributed to equity holders/ owners. Other projects do contribute to the national treasury through these taxes as well. Compared to this project, paying only $2.71 \%$ as royalties and export tax (and no income tax) after commissioning other projects will be paying income tax additionally - this project will be paying about one-fourth of what other projects will be paying. If one is to compute the percolation coefficient of the debt service period only, it comes to 0.28 only which is quite low compared to other projects.

Moreover, as the tariff fixed for export of power from this project is merely US 4.95\$ per unit while NEA is importing at around US $9 \$$ per unit from PTC India Limited, the government revenue from energy royalty to Nepal is commensurately low. ${ }^{10}$

\section{Mark-sheet}

One can easily make an assessment of this project by compiling percolation coefficients due to various linkages, as follows:

\begin{tabular}{|c|c|}
\hline Linkage & Percolation Coefficient \\
\hline Backward linkage & 0.0356 \\
\hline Forward linkage & 0.1 \\
\hline
\end{tabular}

\begin{tabular}{|c|c|}
\hline Investment linkage & 0.01 \\
\hline Fiscal linkage & 0.28 \\
\hline
\end{tabular}

The percolation coefficient in each type of linkage could be higher (closer to 1) but for the structuring (should not be confused with the physical structure of the works) and/ or packaging of this project.

\section{Part V: Recommendations and Conclusion}

In view of the above, the only condition under which Nepal should go ahead with the implementation of this project is by adopting the principles established by the Columbia Treaty. Nepal should receive 325 MW as power benefit under Clause $V$ and payment for flood control under Clause VI which recognizes that the upstream country is entitled to "compensation for the economic loss to Canada arising directly from Canada foregoing alternative uses of the storage used to provide the flood control."

Alternately, India should provide land in exchange of inundated/submerged land of over 4,000 ha pursuant to precedent set by Sarada Agreement of 1920, the 3rd clause of which reads: "That the Nepal Government would transfer necessary land for the construction and maintenance of canal works which is provisionally estimated at 4,000 acres and would receive land equal in area from the British Government" (Pun 2008); because the inundated/ submerged land under the reservoir will never become available for economic/ productive uses by Nepal.

The ideal structure of the West Seti Project is as follows:

\begin{tabular}{|l|l|l|}
\hline \multicolumn{1}{|c|}{ Benefit } & \multicolumn{1}{c|}{ Allocation } & \multicolumn{1}{c|}{ Value } \\
\hline $\begin{array}{l}\text { Good Quality, low } \\
\text { cost power }\end{array}$ & $\begin{array}{l}\text { Exported at } \\
\text { competitive tariff }\end{array}$ & $\begin{array}{l}\text { To maximize royalty } \\
\text { revenue }\end{array}$ \\
\hline Flood Control & $\begin{array}{l}\text { Recompense to Nepal } \\
\text { at reasonable level }\end{array}$ & To be determined \\
\hline $\begin{array}{l}\text { Dry Season } \\
\text { Augmented Flow }\end{array}$ & $\begin{array}{l}\text { Recompense to Nepal } \\
\text { at reasonable level }\end{array}$ & $\begin{array}{l}\text { Rs 5.833 billion per } \\
\text { annum }\end{array}$ \\
\hline $\begin{array}{l}\text { Carbon Trading } \\
\text { Benefit }\end{array}$ & Exclusively to Nepal & $\begin{array}{l}\text { Rs 2.59 billion per } \\
\text { annum }\end{array}$ \\
\hline
\end{tabular}

If above structure is unacceptable to the proponents, then the project should be structured as described in the following lines. It should be built as a multipurpose project in order to irrigateland in Nepal, and the dam height should be fixed according to irrigation need of cultivable land in Nepal. Therefore, the inundation/submergence of land in Nepal should be commensurate to the extent of Nepal's irrigation requirement only. The electricity should be used to meet Nepal's need of peak-in energy demand and export only excess energy to India, not power. Besides, as long term PPAs yield low tariff (and vice versa - depicted by the diagram above), no long term PPA should be executed. Only short term PPA should be signed with an eye on Nepal's need.

The proponents of the project seem to be trying to obfuscate the important (with high value for Nepal) issues by citing indirect benefits to Nepal in terms of employment generation, etc., occurring during construction period, 
which automatically occur in the alternative models recommended above. Similarly, they have a litany of "anticipated spin off benefits", which also does take place in the recommended models above.

Ratna Sansar Shrestha, FCA is a management professional specializing in financial/economic, legal and managerial aspects of water resources sector, mainly hydropower, renewable energy technologies, environmental enterprises, and carbon trading. He is a Fellow of Institute of Chartered Accountants of Nepal, a corporate lawyer accredited by the Nepal Bar Council, a member of Water Tariff Fixation Commission and in the Board of Directors of Everest Bank Ltd. and Butwal Power Company Ltd. He was member of the Board of Director of the NEA in 20022004. He is currently a visiting faculty at the Kathmandu University, School of Engineering, Nepal.

\section{Corresponding address: rsansar@mos.com.np}

\section{Notes}

1. This is no more true. The meeting of the Parliament's Natural Resource and Means Committee held on J uly 17, 2007 has resolved to direct the Government of Nepal to arrange to receive $10 \%$ free power - not revenue in lieu of it.

2. Vernacular daily Kantipur (Kathmandu), May 25, 2009.

3. 'Power import from India unlikely for high tariff', Bangladesh News (December 14, 2007). URL: www. bangladeshnews.com.bd.

4. See Table 3, 'Land Use on Sites to be Permanently Acquired', in WSHL 2007.

5. First signed away in the name of MoU for Tanakpur power project, but after the intervention of Supreme Court, in the name of package deal, Nepal was betrayed by signing a treaty for the whole Mahakali River which was even ratified by the Parliament - an act of national betrayal.

6. A transcript of the interview has been published in Nepali Times (Kathmandu, an English weekly), \#418, 19-25 September, 2008.

7. Based on the precedent set by the agreement between Lesotho and South Africa.

8. Decommissioning means either stopping production of electricity from the plant or the demolition of the civil and electric infrastructure in order to restore the river ecosystem, minimizeor eliminatesafety hazardsand put the river and land resources back to economically productive uses, when the useful life of the project expires.
9. Pursuant to the decision of Natural Resource and Means Committee of the Parliament, the Government of Nepal is required to take $10 \%$ of the electric energy in kind, although the Project Agreement with the proponents of this project (as per the 8th amendment) envisages receiving money in lieu of energy. In this paper, it is assumed that the Government of Nepal will succeed in amending the project agreement to receive energy itself, instead of money in lieu, in order to conform to the Committee's decision.

10. NEA is paying about US $8 \phi$ for electricity generated by RoR (run-of-river) projects in Nepal. As this project is slated to sell electricity at rock bottom prices, Nepal's revenue from this project will also be low. It is interesting to note (by comparison) that Tripura in India proposed to export electricity to Bangladesh at INR 7 (equivalent to US 16థ).

\section{References}

DEFRA, n.d. (UK Department for Environment, Food and Rural Affairs). URL: http:/ / www.defra.gov.uk/ environment/ envrp/gas/10.htm; http:/ / www.defra.gov.uk/ environment/ climatechange/ uk/ individual/ pdf/ actonco2-calcmethodology.pdf.

Dhungel, D.N., S.B. Pun, et al, 2009, 'Inundation at the southern border', in D.N. Dhungel and S.B. Pun, eds., The Nepal-India Water Resources Relationship: Challenges, Kathmandu: Institute of Integrated Development Studies.

Pun, S.B., 2008, 'Whither Indo-Nepal water resource?', in Part V, Vidyut (half yearly edition) 19(1), (August).

Shani, Wallis, 1992, Lesotho Highland Water Project, Surbiton, Surrey, UK: Laserline.

Patel P. \& Ragavan R. (2000): Sustainable Environmental Outcomes from Water-related Energy Projects. In Water Resources Development, Vol. 16, No. 4, 511-524,2000

SMEC, 1997, Detailed Engineering Report of West Seti Hydroelectic Project, Australia: SMEC International Pty. Ltd.

Thapa, A.B., 1995, 'West Seti benefit could turn into a desert mirage for Nepal', WECS Bulletin 6 (May).

Thapa, A.B., 2008, 'International water right principles', Newsfront (Kathmandu) 84 (15-21 September). URL: www. bhrikutinews.com/newsfront/.

UNEP/IPCC, n.d. URL: http://www.ipcc-nggip.iges.or.jp/ EFDB/find_ef.php.

WSHL, 2007, Environmental Assessment Report of West Seti Hydroelectric Project, Report to the Asian Development Bank, New Delhi: West Seti Hydro Ltd. 